\title{
A Case of Paratesticular Atypical Lipomatous Tumor/Well-Differentiated Liposarcoma
}

\section{Paratestiküler Atipik Lipom/lyi Diferansiye Liposarkom Olgusu}

\author{
Hikmet Köseoğlu1, Kutsal Yörükoğlu2 \\ 1 Başkent University Faculty of Medicine, Department of Urology, Istanbul, Turkey \\ 2Dokuz Eylül University Faculty of Medicine, Department of Pathology, Izmir, Turkey
}

\section{ABSTRACT}

A very rare case of paratesticular atypical lipomatous tumor/a case of welldifferentiated liposarcoma diagnosed in an elderly patient is presented together with macroscopic surgical photographs and photographs of microscopic pathological sections.

\section{Key Words}

Paratesticular, mass, liposarcoma, orchiectomy

\section{ÖZET}

Olgu sunumunda ileri yaştaki bir hastada tanı konulan oldukça nadir görülen paratestiküler atipik lipom/iyi diferansiye liposarkom olgusu makroskopik cerrahi ve patolojik görüntüleri eşliğinde sunulmaktadır.

\section{Anahtar Kelimeler}

Paratestiküler, kitle, liposarkom, orşiektomi

\section{Introduction}

Soft tissue cancers, so called sarcomas, have a very low ratio among all cases of cancer; as well paratesticular liposarcoma occurs very rarely compared to many other soft tissue cancers $(1,2,3)$. Therefore in this case report, a paratesticular liposarcoma diagnosed in an elder man is presented together with macroscopic surgical photographs and photographs of microscopic pathological sections.

\section{Case Report}

An 85 year old man admitted to the urology clinics for painless huge scrotal swelling which had increased in size within last 5 years and for walking difficulty due to this huge scrotal swelling. The physical examination revealed normal bilateral testicles together with $3 \mathrm{~cm}$ firm solid mass next to the left epididymis and huge soft tissue fulfilling the left scrotum with an approximately $10 \mathrm{~cm}$ diameter. Ultrasonography and Doppler studies detected no testicular mass but a left scrotal solid, hyperechoic and heterogeneous mass without clear cut borders. Under spinal anesthesia, the patient was performed radical high inguinal orchiectomy and left spermatic cord, left testis and paratesticular mass was resected out en bloc (Figure 1). Macroscopic pathological examination revealed a partially encapsulated $11 \times 9.5$ $\mathrm{cm}$ soft yellow colored paratesticular mass compressing spermatic cord and causing fluid accumulation around the testis and a $3.5 \times 3.3$ $\mathrm{cm}$ solid cream colored encapsulated paratesticular mass which was lobulated with fibrotic bands (Figure 1).

The histopathological evaluation revealed atypical lipomatous tumor/ well-differentiated liposarcoma with negative surgical margins (Figure 2). There were no abnormal findings in the postoperative abdominal computed tomography. The patient is still under follow up with an uneventful postoperative period of 18 months.

\section{Discussion}

Sarcomas have a ratio of $0.7 \%(11.280 / 1.638 .910)$ irrespective of sex within estimated annual new cancer cases in the USA (1). However, genitourinary sarcomas are very rare such that retrospective patient database analyses of past 25 year period between 1997 and 2013 in the Memorial Sloan Kettering Cancer Center detected 131 cases of genitourinary sarcomas (2). Again, a multi-centered study in Toscana, a wide region of Italy, reported 22 cases with genitourinary sarcomas within a period of 18 years (3). In both studies above mentioned the most common histological sub-types of sarcomas were leiomyosarcoma (29\% and 37\% respectively) and liposarcoma (26\% and $27 \%$ respectively) $(2,3)$. The most common reported location of

\section{Correspondence}

Hikmet Köseoğlu MD, Başkent University Faculty of Medicine, Department of Urology, İstanbul, Turkey

Phone: +90 5305519933 E-mail: hikmet.koseoglu@gmail.com Received: 25.11.2014 Accepted: 20.01.2015 


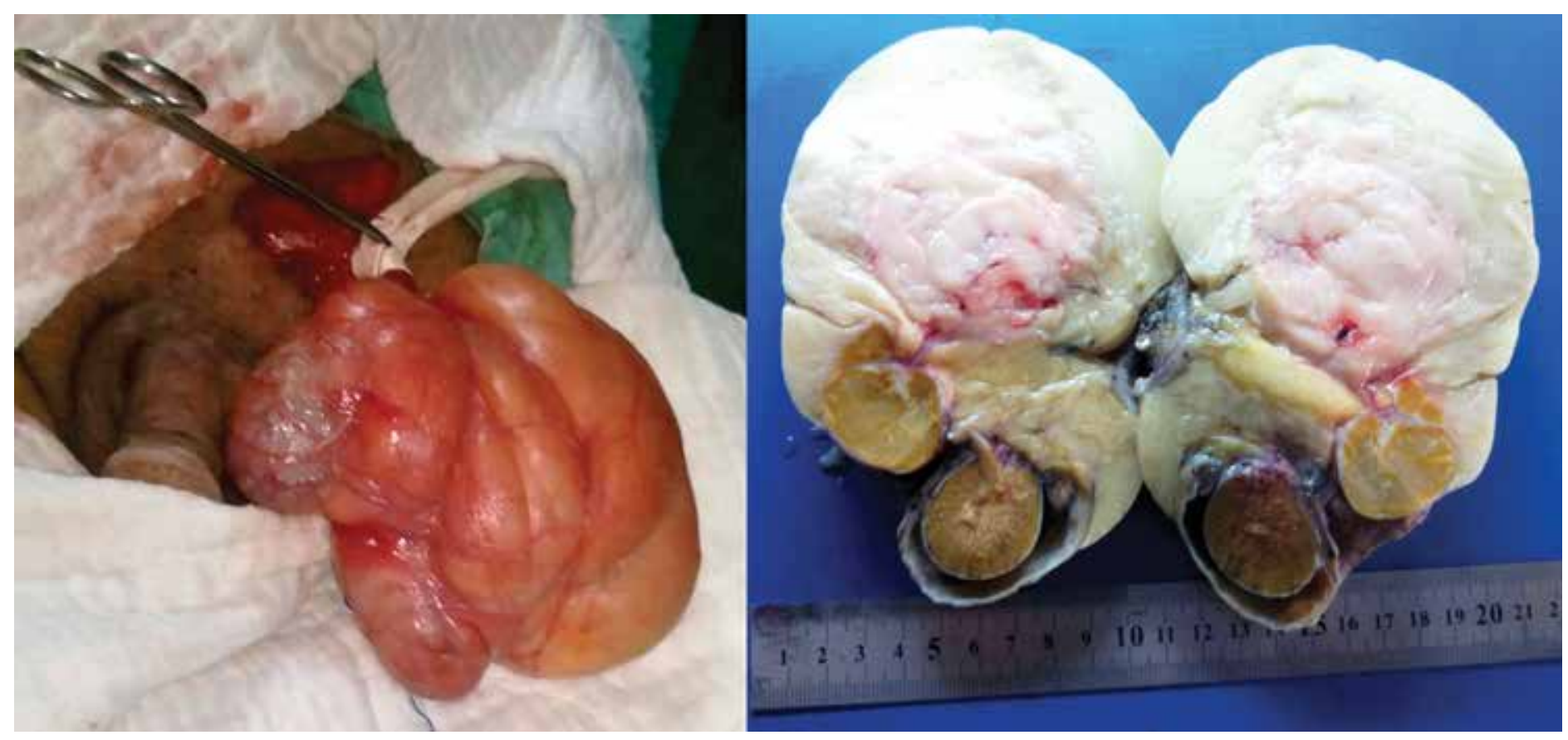

Figure 1. Macroscopic appearance of paratesticular mass during surgery (on the left). Macroscopic cut view of the specimen (on the right)

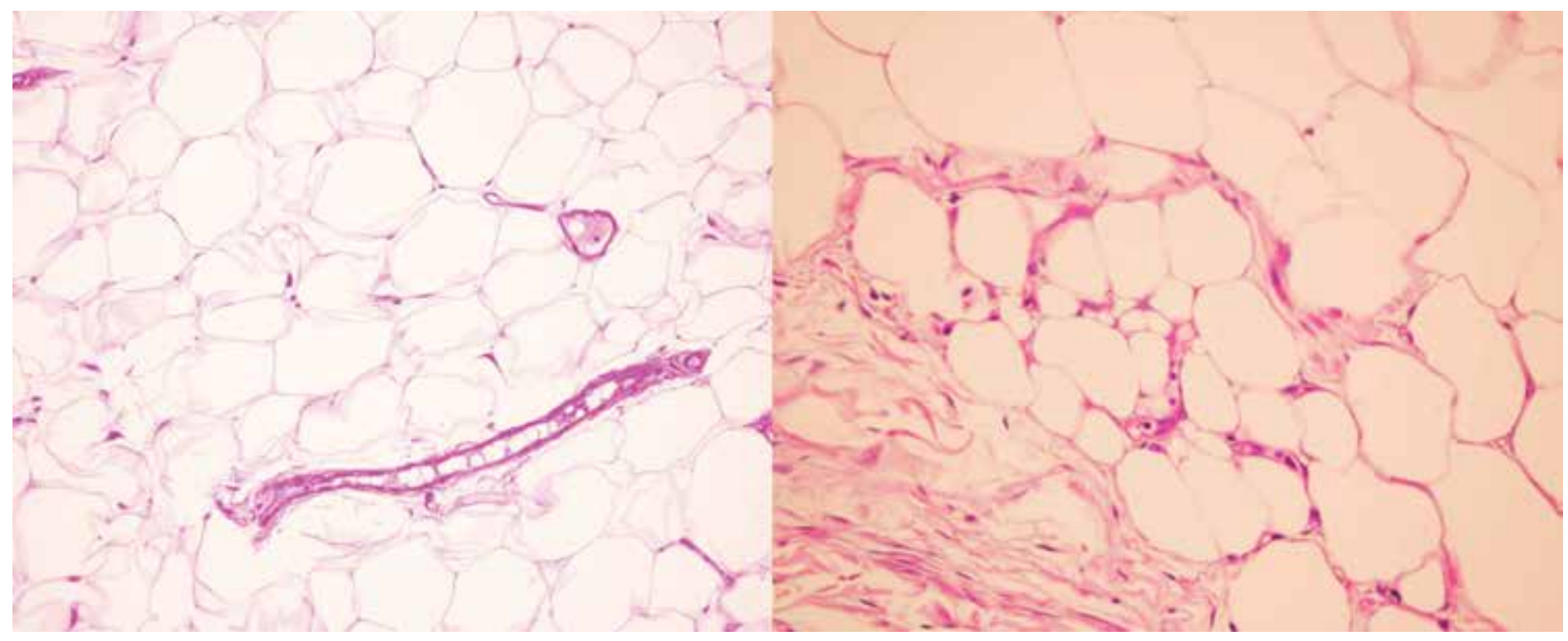

Figure 2. Microscopic view of diffuse atypia in the stromal cells (on the left) (H\&E, x200). Microscopic view of atypia in the stromal cells in the proximity of the fibrous band and a lipoblast (on the right) $\left(H \& E_{1} \times 400\right)$

the genitourinary sarcomas is paratesticular area (44\% and $41 \%$ ) and the most common histological sub-type of paratesticular sarcomas is liposarcoma $(56 \%)(2,3)$.

Compared to the other histological variants of sarcomas, liposarcomas have a tendency to be low grade histologically $(2,4)$. Sarcomas generally have a bigger size at time of diagnosis, thus they may necessitate resection of organs in the close proximity for their complete resection $(2,4,5)$. Well differentiated sarcomas have a tendency to recur locally whereas undifferentiated ones have a tendency to make diffuse metastases (4). However, both well differentiated sarcomas and undifferentiated ones, especially retroperitoneal ones necessitating resection of organs in the close proximity, have been reported to be more aggressive biologically (6). Thus, en bloc resection of liposarcomas together with organs next to them seems to be more proper in case of gross mass volume and/or no clear surgical plane of resection between mass and organs in the close proximity. In this present case, due to these reasons together with his rather elder age, radical inguinal orchiectomy was performed.

Disease specific survival of sarcomas is affected by factors like anatomical location, tumor size and grade, presence of local recurrence or metastasis and incomplete resection $(2,3,4)$. Low grade liposarcomas in the extremity or upper body have a 5-year 
survival rate of $95 \%$ whereas this rate falls to $50 \%$ in the high grade retroperitoneal or visceral liposarcomas (4). In case of genitourinary sarcomas, in accordance with other variants of sarcomas, general survival is affected by location, grade and size of tumors (3). Tumor diameter above $5 \mathrm{~cm}$, high histological grade and non-paratesticular location of tumor were associated with poor prognosis (3). The survival rates of paratesticular sarcomas were reported as 88.9\%, 88.9\% and 74.1\% for 1-year, 3-year and 5 year periods respectively (3). Though surgery was generally reported to be sufficient for the treatment of paratesticular sarcomas, adjuvant doxorubicin-based chemotherapies were given in case of worse histological types like rhabdomyosarcoma and fibrous histiocytoma (3).

As a conclusion, paratesticular sarcomas are seen very rare and surgical en bloc resection is necessary in the treatment of these paratesticular sarcomas.

\section{Conflict of interest}

There are no conflicts of interest.

\section{References}

1. Siegel R, Naishadham D, Jemal A. Cancer statistics, 2012. CA Cancer J Clin 2012;62:10-29.

2. Dotan ZA, Tal R, Golijanin D, Snyder ME, Antonescu C, Brennan MF, Russo P. Adult genitourinary sarcoma: the 25-year Memorial Sloan-Kettering experience. J Urol 2006;176:2033-2038.

3. Mondaini N, Palli D, Saieva C, Nesi G, Franchi A, Ponchietti R, Tripodi S, Miracco C, Meliani E, Carini M, Livi L, Zanna I, Trovarelli S, Marino V, Vignolini G, Pomara G, Orlando V, Giubilei G, Selli C, Rizzo M. Clinical characteristics and overall survival in genitourinary sarcomas treated with curative intent: a multicenter study. Eur Urol 2005;47:468-473.

4. Linehan DC, Lewis JJ, Leung D, Brennan MF. Influence of biologic factors and anatomic site in completely resected liposarcoma. J Clin Oncol 2000;18:1637-1643.

5. Lee G, Lee SY, Seo S, Jeon S, Lee H, Choi H, Jeong BC. Prognostic factors and clinical outcomes of urological soft tissue sarcomas. Korean J Urol 2011;52:669-673.

6. Singer S, Antonescu CR, Riedel E, Brennan MF. Histologic subtype and margin of resection predict pattern of recurrence and survival for retroperitoneal liposarcoma. Ann Surg 2003; 238:358-370.22 